\title{
ROLE AND CREATIVITY OF PROACTIVE PERSONAL IN CREATIVE INDUSTRIAL SECTOR OF ENTREPRENEURSHIP
}

\author{
Utomo Fajar Cahyo* \\ Doctoral Program, University of Merdeka Malang, Indonesia \\ Sanusi Anwar, Manan Abdul \\ University of Merdeka Malang, Indonesia \\ *E-mail: fajarcahyoutomo@unkris.ac.id
}

\begin{abstract}
The purpose of this paper is to explore the relationship between proactive personalities towards entrepreneurship. This paper proposes creativity as a mediation to see an increasing change in entrepreneurship. Data was taken through targeted sampling strategies from 153 fashion subsector entrepreneurs. The hypothesis is tested by structural equation modeling. The findings show that there is a positive relationship between proactive personality towards entrepreneurship mediated by creativity. The value of this paper is one of the first to explore the relationship between a proactive personality and creativity towards entrepreneurship. This fact also supports the argument that entrepreneurship really requires creativity to be able to compete and continue to grow in the creative industry.
\end{abstract}

\section{KEY WORDS}

Proactive personality, creativity, entrepreneurship, industry.

Entrepreneurship is experiencing a relatively rapid change from day to day. Current changes are fast enough to force business people to be able to adapt to these changes. The need for a new perspective to be able to compete is needed by entrepreneurs. Concepts such as the hyper power of competition, in speed, aggression, adaptability and flexibility can reflect the field of entrepreneurship. Therefore, entrepreneurs today must be flexible, and strategic. Regarding this, many researchers in the literature discuss entrepreneurship which is associated with proactive personality and creativity (Dogan, 2015). At present, entrepreneurship for the creative economy in developed countries in the formation of gross domestic income or GDP is very large and even shifts other economic sectors. The growth of the creative industry in Singapore grew by an average of $2.8 \%$, in the UK it reached $8.2 \%$ and Australia 5.7\%. While the growth of the creative industry in Indonesia, seen from its contribution to GDP in 2008 amounted to $7.28 \%$, absorption of employment is 7.6 million and its role in exports amounted to 114.9 trillion (Plan for the development of Indonesia's creative economy 2009-2025, Ministry of Trade of the Republic of Indonesia, 2008).

The role of entrepreneurship in economic growth does not merely increase output and income per capita, but also involves the introduction or application of changes in business structure and society (Hisrich, et. Al, 2008). Timmons and Spinelli (2004) describe the evolution of entrepreneurship that has changed the world in the past 40 years into four forms of entrepreneurial transformation. Entrepreneurial transformation can influence how the world community lives their daily lives, works, studies, and enjoys leisure time. The four transformations consist of entrepreneurship as a new paradigm in management; entrepreneurship as a new paradigm in education; entrepreneurship as a new paradigm in non-profit business management and philanthropy; and entrepreneurship as a curriculum in business schools.

The creative economic era of the individual's role reflected in one's personality is needed in developing an entrepreneurship. Highly proactive individuals are able to identify opportunities and take appropriate actions to take advantage of opportunities, and defend them until significant changes occur (Crant 1996). The idea of creative industries 
in developed countries is developed on concepts and phenomena, many developing countries have begun to adopt these ideas as a medium to build a region or city (Fahmi, Koster and van Dijk, 2016). Researchers argue that to make a region of the creative industry is the most important thing for advancing the region. Developing a creative industry is not independent of the creativity of the people in the region, where the effect of creativity in entrepreneurship is empirically influential (Baron and Tang, 2011). The most important contribution from the results of this research is that creativity can influence important activities in business activities, especially in the creative industry sector.

Finally, by inputting creativity as a mediating variable, this study reflects the recommendations of (Baron and Tang, 2011) for applying a multi-level approach in an effort to understand the phenomenon of entrepreneurship in complex creative industries. This approach has been used in several branches of management, but has just been adopted for entrepreneurial research. The researcher believes that the mediation model proposed is an application that is useful for gaining insight into key aspects of entrepreneurship. Furthermore, researchers describe the theoretical and empirical foundations of this model and obtain specific propositions that can be further tested.

\section{LITERATURE REVIEW}

The positive relationship between proactive personality and creativity, where the proactive person is a very important part of increasing creativity in the work environment (Kim et.al, 2010). This research indicates that a person with a proactive personality will tend to be resistant to all forms of external pressure and will influence changes to the environment by observing observant opportunities, showing high initiative so that they can take actions that will bring positive change in a work environment. Broadly speaking, workers who are assumed to be proactive will produce a high level of creativity when compared to workers who do not have a proactive personality. Creativity that is supported by the ability to innovate in entrepreneurship also influences the development of entrepreneurship, especially in the small and medium industrial sector (Hadiyati, 2011). Entrepreneurship grows and develops due to the proactive personality possessed by dominant entrepreneurs will influence the daily activities of entrepreneurs. Proactive in seeing new opportunities to get orders, and seeking for new information is a real support made by entrepreneurs to run their business (Handayani et.al, 2014).

Referring to previous research, the grand theory used is Drucker's concept (1959), where entrepreneurship is a way for someone to create opportunities by using existing resources in forming or creating a new business. The indicator used as a measure for entrepreneurship is commitment; ambitious; take risks; confidence; inventive; feedback; hard work; excellence; future oriented; learn from failure and leadership (Zimmerer, 1996). The development of entrepreneurship in a region is also supported by creativity in developing oneself into a creative entrepreneur. Creativity is defined as a person's ability to create problem solving ideas (Zimmerer, 1996). The indicator used to measure this creativity variable is having a creative idea; have conceptual; originality; complexity and skill (Campbell, 1986). The dynamic development of entrepreneurship in the creative industry has led to changes in the business environment. With the proactive personal character that is possessed, it can make entrepreneurs stay in their business. Proactive personality is conceptualized by researchers as the ability of a person not to be easily influenced by the environment and able to create changes in his environment (Bateman \& Crant, 1993). Proactive personality is measured by indicators of responsibility, focus on work, giving examples, having principles and uniqueness (Covey, 1989).

\section{METHODS OF RESEARCH}

The methodology for looking at proactive personal roles and creativity in entrepreneurship uses statistical structural equation modeling (SEM) techniques and includes procedures and considerations involved in SEM (Hershberger, Marcoulides and 
Parramore, 2009). Some of the considerations used are correlation matrix and good of fit index (McDonald and Ho, 2002). Tests were carried out on the textile industry as many as 153 entrepreneurs. The amount is obtained by using the Slovin formulation with formula $n=$ $\mathrm{N} /(1+\mathrm{Ne} 2)$ with the total entrepreneur population of 618 and alpha level of $7 \%$ (Stephanie, 2012). Sampling from the existing population uses simple random sampling which is commonly used in different business units (Pathak, 1988). All entrepreneurs were given questionnaires in the form of statements that had been given answers (Ornstein, 2014). Answers are provided using a Likert scale and given a score of 1 to 5 (Mclver and Carmines, 2011).

\section{RESULTS AND DISCUSSION}

Figure 1 is the result of a structural equation model. Model suitability assessment is carried out by considering eight criteria of Goodness of Fit Index of models. As shown in figure 1, the results of the assessment of the suitability of the model, namely Chi Square, Probability, RMSEA and GFI have good value, AGFI has a marginal value, CMIN / DF has good value, TLI has value well and CFI has good value. Based on the above explanation regarding the Goodness of Fit criteria, it can be concluded that only AGFI has a marginal value while the other measurements can be said to be good. The value of the factor loading of each indicator on proactive personal variables, creativity and entrepreneurship has a value greater than 0.50 and the value of the critical ratio $(\mathrm{CR})$ of each indicator greater than 2.0. This gives the conclusion that each indicator is significantly a dimension of proactive, creative and entrepreneurial personal variables.

The assumptions testing used in this study include normality test, outlier test and multicollinearity test. Based on the results of the tests that have been carried out, it can be concluded that the normality test results in the distribution of normally distributed data so that the data obtained can be used as a basis for further analysis, whereas for Outlier testing produces data that have no outliers in the research data. Multicollinearity testing concluded that the entire data used in this study is feasible for further analysis.

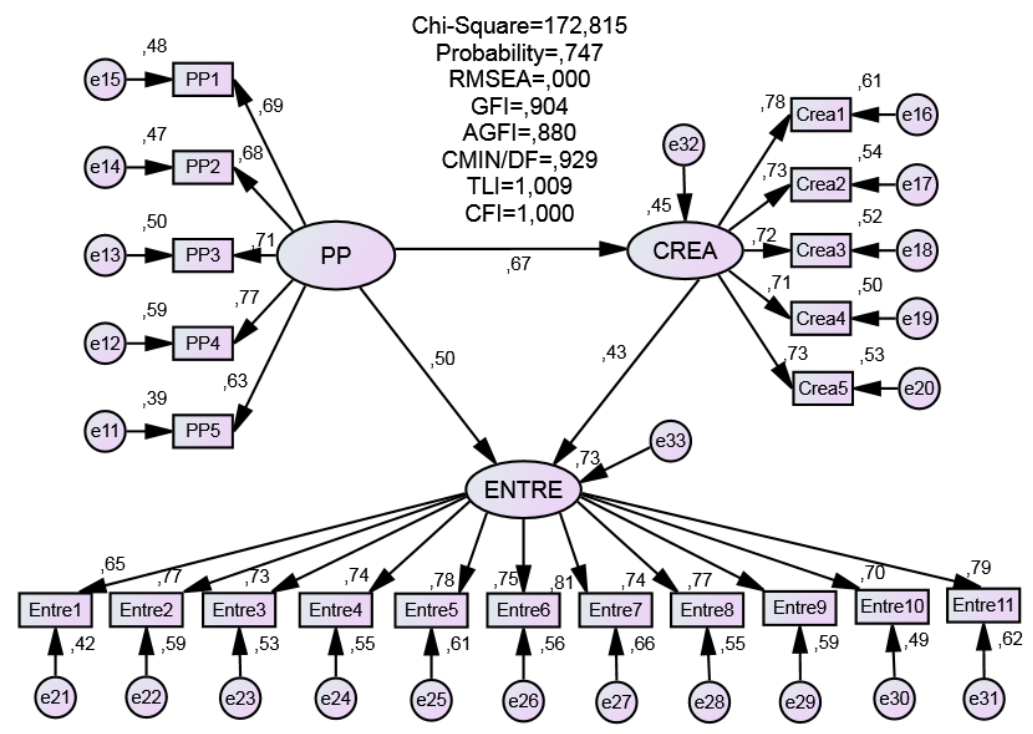

Figure 2 - Full Standardizer Structural Equation Modeling

The results of the path coefficients of influence between variables are as follows: $(\mathrm{H} 1)$ the value shows that the proactive person has a direct effect on creativity, the probability value on the proactive personal variable is $0,000>0.05$, based on this result $\mathrm{HO}$ is rejected and $\mathrm{H} 1$ is accepted. The coefficient value shows a positive value, meaning that there are active personal changes to creativity; (H2) states that the proactive person has a direct effect on entrepreneurship, the probability value of the proactive personal variable is $0,000>0.05$, 
based on these results $\mathrm{HO}$ is rejected and $\mathrm{H} 2$ is accepted. If the proactive person experiences positive changes it will also have a positive impact on entrepreneurship, this condition can be reflected in the value of the coefficient that has a positive value; $(\mathrm{H} 3)$ the third hypothesis states that creativity has a direct effect on entrepreneurship, the value of probability in the creativity variable is $0,000>0.05$, based on these results $\mathrm{HO}$ is rejected and H3 is accepted. There are clear changes if creativity increases, entrepreneurship also increases and vice versa; $(\mathrm{H} 4)$ the fourth hypothesis is acceptable, that creativity is able to be mediation for a proactive person in increasing entrepreneurship. these results can be reflected in the total value greater than the indirect value $(0.843<0.288)$. Following table 1 presents the results of hypothesis testing, and then the hypothesis is tested using analysis of structural equation modeling.

Table 1 - Results of Inter Variabel Effect Line Coefficients

\begin{tabular}{|c|c|c|c|c|c|c|c|}
\hline \multirow{3}{*}{ Hyp } & \multicolumn{3}{|c|}{ Variable } & \multicolumn{4}{|c|}{ Regression Coefficient } \\
\hline & \multirow{2}{*}{ Exogenous } & \multirow{2}{*}{ Mediation } & \multirow{2}{*}{ Endogenous } & \multicolumn{2}{|c|}{ Direct Effect } & \multirow{2}{*}{ In-direct effect } & \multirow{2}{*}{ Total } \\
\hline & & & & Coef. & Prob & & \\
\hline $\mathrm{H}_{1}$ & PP & Crea & - & 0,672 & 0,000 & - & - \\
\hline $\mathrm{H}_{2}$ & PP & - & Entre & 0,505 & 0,000 & - & - \\
\hline $\mathrm{H}_{3}$ & & Crea & Entre & 0,428 & 0,000 & - & - \\
\hline $\mathrm{H}_{4}$ & PP & Crea & Entre & - & - & 0,288 & 0,843 \\
\hline
\end{tabular}

Source: Primary Data, 2018.

The creative industry, especially its fashion development, cannot be separated from how entrepreneurs have the ability to quickly grasp the opportunities that exist by utilizing the resources owned by these entrepreneurs (Drucker, 1959). These opportunities can be obtained from the hard work of entrepreneurs in creating fashion products to have more competitiveness in their industry. hard work is the most dominant factor in entrepreneurship based on the results of the value factor loading. While the factor that needs to be considered for improvement is the commitment of entrepreneurs to always meet the needs of users of their products. Creative industries in a region can grow if people in the region have an active personality in entrepreneurship. Proactive entrepreneurial personality can be seen from its ability to create good change for other entrepreneurs (Batement and Crant, 1993). The community can create a change, the entrepreneur must have the principle of bringing the fashion industry to continue to be developed and be able to compete with other industries. The real form is to provide an example of always focusing on work and responsibility for all the activities he does. Then the very important nature needs to be improved in terms of the proactive personal attitude towards entrepreneurship is the nature of uniqueness. The rapid development of the fashion industry also encourages entrepreneurs to have the ability to create new ideas in capturing opportunities with their creativity (Zimmerer, 1996). The ability to deal with the complex problems that are always faced is the main factor that must exist in a fashion entrepreneur to get opportunities that are accompanied by skills in producing better product design, whereas to be able to consolidate the concept of business, entrepreneurs must have strong principles.

There are several limitations in our study. The use of samples that only focus on the fashion sub-sector in the creative industry is considered by researchers to have not been able to fully describe the facts of entrepreneurship in creative industries in a region. Respondents who are the object of research are entrepreneurs in small and medium business groups. The current situation in the creative industry, which is marked by major and rapid changes after the digital revolution, and the benefits of the roadmap as a means for the Creative Industry (Abbasi, Vassilopoulou and Stergioulas, 2017). To maximize the use and value of technology in the Creative Industry must focus on technology that facilitates entrepreneurs. It is recommended to put in the information technology variable to provide further verification of entrepreneurship theory for the creative industry. 


\section{CONCLUSION}

Entrepreneurs in Bandung's fashion creative industry run their business based on the proactive personality that exists in individual entrepreneurs, so creativity to develop ideas with intellectual abilities and find new ways to get opportunities can also be created. Entrepreneurship in the city of Bandung grows because the entrepreneur has the intellectual ability to create an opportunity with the proactive personality that the entrepreneur has. Entrepreneurship can be created if the entrepreneur is personally proactive with responsibility as the main characteristic in completing work. The fashion industry players in the city of Bandung are currently paying attention to the factors of creativity in carrying out their business activities. Businesses in the fashion industry are recognized by entrepreneurs as having to have the creativity to complete very complex jobs as a preferred factor if they want to survive in the industry. In general, creative people prefer complexity than convenience, choosing challenges rather than security. So that the ability to compete in the creative industry will create new markets share in the fashion business. Entrepreneurship in the fashion industry currently requires considerable creativity from business people in the industry. Facts prove that creativity is a factor that is able to mediate proactively the person itself, so that a new business can be created and have the characteristics of the products that being produces.

\section{ACKNOWLEDGMENTS}

This work was supported by University of Krisnadwipayana through doctoral program education grants and under the guidance of professors at University of Merdeka Malang.

\section{REFERENCES}

1. Abbasi, M., Vassilopoulou, P. and Stergioulas, L. (2017) 'Technology roadmap for the Creative Industries', Creative Industries Journal. Routledge, 10(1), pp. 40-58. doi: 10.1080/17510694.2016.1247627.

2. Baron, R. A. and Tang, J. (2011) 'The role of entrepreneurs in firm-level innovation: Joint effects of positive affect, creativity, and environmental dynamism', Journal of Business Venturing. Elsevier Inc., 26(1), pp. 49-60. doi: 10.1016/j.jbusvent.2009.06.002.

3. Bateman, T. S., \& Crant, J. M. 1993. The proactive component of organizational behavior: A measure and its correlates. Journal of Organizational Behavior, 14: 103-118.

4. Campbell, David. 1986. Mengembangkan Kreativitas. Yogyakarta: PT Kanisius.

5. Covey. 1989. Proactive Model. Jakarta, Erlangga.

6. Crant, Michael. J. (1996) 'The proactive personality scale as a predictor of entrepreneurial intentions. Charts The Proactive Personality Scale As A Predictor Of Entrepreneurial Intentions', Journal of Small Business Management 96 vol: 34 (3)

7. Dogan, N. (2015) 'The Intersection of Entrepreneurship and Strategic Management: Strategic Entrepreneurship', Procedia - Social and Behavioral Sciences. Elsevier B.V., 195, pp. 1288-1294. doi: 10.1016/j.sbspro.2015.06.290.

8. Drucker, P. F 1959. The landmark of Tomorrow, New york: Harper and Bros

9. Fahmi, F. Z., Koster, S. and van Dijk, J. (2016) 'The location of creative industries in a developing country: The case of Indonesia', Cities. doi: 10.1016/j.cities.2016.06.005.

10. Hadiyati, E. 2011. Kreativitas dan Inovasi Berpengaruh Terhadap Kewirausahaan Usaha Kecil. Jurnal Manajemen dan Kewirausahaan, Vol. 13 (1), 8-16.

11. Handayani, N. U. Santoso, H., Susanto, Y. I. Faktor-Faktor yang Berpengaruh Terhadap Kewirausahaan di Klaster Industri Mebel Kabupaten Blora. 2014. J@TI Undip. Vol IX (1), 11-18.

12. Hershberger, S. L., Marcoulides, G. A. and Parramore, M. M. (2009) 'Structural equation modeling: an introduction', in Pugesek, B. H., Tomer, A., and von Eye, A. (eds) Structural Equation Modeling. Cambridge: Cambridge University Press, pp. 3-41. doi: 10.1017/CBO9780511542138.002. 
13. Hisrich, R.D, Peters, M.P., \& Shepherd, D.A. 2008. Enterpreneurship: Mc Graw hill International edition.

14. Kim,T.Y., Hon, Alice. H.Y.,\& Lee,D.R. 2010. Proactive Personality and Employee Creativity: The Effects of Job Creativity Requirement and Supervisor Support for Creativity Creativity Research Journal, 22(1), 37-45.

15. McDonald, R. P. and Ho, M. H. R. (2002) 'Principles and practice in reporting structural equation analyses', Psychological Methods. doi: 10.1037/1082-989X.7.1.64.

16. Mclver, J. and Carmines, E. (2011) 'Likert Scaling', in Unidimensional Scaling. doi: 10.4135/9781412986441.n3.

17. Ministry of Trade of the Republic of Indonesia. 2008. Rencana pengembangan ekonomi kreatif Indonesia 2009-2025.

18. Ornstein, M. (2014) 'Designing a Questionnaire', in A Companion to Survey Research. doi: 10.4135/9781473913943.n3.

19. Pathak, P. K. (1988) '4 Simple random sampling', Handbook of Statistics. doi: 10.1016/S0169-7161(88)06006-7.

20. Stephanie (2012) Slovin's Formula: What is it and When do I use it? - Statistics How To, May 14, 2012.

21. Timmons, J.A. \& Spinelli, S. 2004. New Venture Creation. (Terjemahan Julianto Agung Saputro). London: McGraw.

22. Zimmerer. 1996. Enterpreneur and New Venture Formation. New Jersey: Prentice Hall international Inc. 